\title{
POLITICAL NEWS AND STOCK PRICES: THE CASE OF SADDAM HUSSEIN CONTRACTS
}

\author{
Yakov Amihud* \\ Stern School of Business \\ New York University \\ Avi Wohl \\ Faculty of Management \\ Tel Aviv University
}

\begin{abstract}
:
This paper studies the association between the market's expectations of Saddam Hussein's fall from power, as reflected in "Saddam contract" prices, and stock prices, oil prices and exchange rates. During the war, a rise in the probability of Saddam's fall, which also indicated a speedy end to the war, was positively and significantly associated with stock prices, strengthened the dollar against the Euro, and lowered oil prices. Before the war, a rise in the probability of Saddam's fall, which may also have indicated the probability of a costly war breaking out, lowered stock prices, which adjusted gradually to this information.
\end{abstract}

Key words: political risk, war and the stock market, war and exchange rates

JEL No: E6, G1, G14, H56.

Revised, July 2003

Forthcoming: Journal of Banking and Finance

We thank an anonymous referee for helpful comments and suggestions and Mr. John Delaney, CEO of Tradesports, for providing the data.

* Ira Leon Rennert Professor of Finance.

Corresponding author. E-mail: yamihud@stern.nyu.edu

(C) 2003 by Yakov Amihud and Avi Wohl. Please do not quote without the authors' permission 


\section{Introduction}

Early in the morning of March 20, 2003 (Iraq time), the U.S. launched about 40 missiles at a site where Saddam Hussein had been thought to be present, thus starting the second Gulf War. Months earlier, President George W. Bush had declared his intention of toppling Saddam Hussein and changing Iraq's regime, and the world had been expecting a possible outbreak of war since the summer of 2002. It was stalled because of political hurdles and maneuvers and because it took time to amass the military forces that would launch the war. This paper examines the effects of these events on stock prices in the U.S.

It is difficult to study the effects of political events on the economy because of the scarcity of data on the public's expectations about forthcoming events before they actually occur. Cutler, Poterba and Summers (1989) examined the effect on stock prices of 49 non-economic world news items between 1941 and 1987 and concluded that they had "surprisingly small effect" (p. 8) ${ }^{1}$. Cutler et al. (1989) also found that publicly available macroeconomic news on fundamental values explained less than half of the variance in aggregate stock prices. This led Cutler et al. (1989) to suggest that moves in stock prices reflect something other than news about fundamental values. "Although the hypothesis that stock prices move in response to news that is observed by market participants but not by investigators studying the markets is irrefutable, we are skeptical of this possibility" (p. 9). Indeed, events are often preceded by expectations that are not observed by researchers and thus part of the effect of news on stock prices is already incorporated in the prices by the time the event is announced. This leads to an

\footnotetext{
${ }^{1}$ Frey and Kucher (2000) and Waldenstrom and Frey (2002) find significant effects of political events, around and during the Second World War on European government bond prices.
} 
underestimation of the effect of the event's announcement on stock prices. There are also cases where expectations that affect stock prices do not materialize and therefore the events are not observed, thus the effects of the would-be events cannot be studied.

In this study, we resolve the problem of measuring the effects of expectations about political and economic events by using market-determined odds of Saddam Hussein's fall from power. In the fall of 2002, the web site Tradesports.com, which provides a platform for on-line betting, initiated a contract that promised $\$ 10$ on the expiration day of the contract if Saddam Hussein was out of power ("not recognized internationally as the leader of Iraq") by then. This web site, which operates from Ireland, is organized as an electronic exchange with an open limit order book. The prices are quoted in integers between 0 and 100 (100 means $\$ 10)$. Thus, the price reflected the probability of Saddam's fall from power by the expiration of the contract (ignoring risk premium considerations). The fees were $0.4 \%$ for buy $/$ sell $/$ payment. The market was quite active when the likelihood of war increased, and there were days with many intraday transactions.

We use the prices of these contracts, which we call "Saddam contracts," as a market-based measure of the probability of Saddam's fall by a specified time (the contract's expiration day). We assume that traders in these contracts reflected in their actions the general public view at that time, and thus the contract prices reflected the market's beliefs about the probability of Saddam's fall. Our study examines the relationship between these beliefs and the stock market by studying the relationship between the Saddam contract price changes and stock returns. 
This raises the question: what information is reflected in the Saddam contract prices and what is its economic meaning. We propose that there is a distinction between the economic information conveyed by these prices before the war and during the war. Consider first the pre-war period. Then, a rise in the Saddam contract price had two conflicting meanings. A rise in the Saddam contract price meant an increase in the probability of war, which means greater economic cost and greater uncertainty about the future course of the economy. This has negative effect on the economy. Nordhaus (2002) estimated that the cost of war would depend on its duration. A short and successful war would cost $\$ 99$ billion, whereas the cost of a prolonged war would reach $\$ 1.924$ trillion, more than 19 times higher. This burden on the economy would erode the value of stocks. The problem with the war is thus both its high expected costs and the uncertainty that it introduces, as evident from the large range of outcomes calculated by Nordhaus (2002). Greater economic uncertainty raises the risk premium demanded by investors and consequently reduces stock prices. Political risk is known to negatively affect asset prices. Using proxies from the exchange rate market in Mexico, Bailey and Chung (1995) showed that increased political risk there raised the equity market premiums for exposure to this risk and subsequently lowered equity prices. Erb, Campbell and Viskanta (1995) demonstrated that uncertainties brought about by inflation raise the equity risk premium and lowered stock prices. Nordhaus (2002) indeed noted that inflation could be one outcome of a prolonged war due to rising oil prices. It follows that both the expected cost of the war and the high uncertainty that it would entail meant that a rise in the probability of war should have negative effect on stock prices. 
On the other hand, the U.S. government claimed that ousting Saddam Hussein would reduce the risk of future terror attacks and enable an increase in the supply of oil after the sanctions on Iraq were lifted. This would produce economic benefits that would have a positive effect on the stock market. Thus, the information reflected in the price of the Saddam contract was mixed before the war. If the dominant interpretation is that higher price means greater likelihood of a costly war with higher economic uncertainty, then the information conveyed by a rise in the Saddam contract price is economically negative.

However, conditional on the war breaking out, a rise in the probability of Saddam's fall was related to the speed with which the war was fought and meant a fast and successful conclusion of the war. That is, all new information after the war begun was about how quickly it would be won. Following Nordhaus (2002) analysis, a fast conclusion of the war would considerably lower its cost (it is reasonable to assume that the cost of war is rising with the length of the war). This would be beneficial for the U.S. economy. Also, a quick ending to the war narrows the possible range of outcomes and lowers economic uncertainty, which in turn reduces the risk premium required by investors. Both the lower expected cost and the lower uncertainty about the cost should make stock prices rise. In addition, the benefits from ousting Saddam Hussein, such as reduced risk of terror attacks and lower oil prices, would accrue sooner and help raise stock prices.

Thus, while before the war, a rise in the Saddam contract price included mixed or negative economic information, once the war actually broke out, a rise in the Saddam contract price meant good news for the U.S. economy. 
These changing interpretations of the Saddam contract prices are reflected in our findings. Before the war, the effect on stock prices of changes in the probability of Saddam's fall was weakly negative, while during the war these changes had a strong positive effect on stock prices. Similarly, we find that during the war, oil prices reacted negatively to expectations about Saddam's fall and the U.S. dollar strengthened against the Euro. Before the war, the effects were opposite (though the statistical significance of the results was low).

In what follows, we present our results on the association between the market's expectations on Saddam's fall and the stock market in Section 2. In Section 3 we discuss the differences between our results and those of a related study by Leigh, Wolfers and Zitzewitz (2003). We offer concluding remarks in Section 4.

\section{Empirical evidence}

\subsection{Data}

We use three Saddam contracts:

1. The March 2003 contract, which started on September 24, 2002 and expired worthless at the end of March 2003,

2. The June 2003 contract, which started on September 24, 2002,

3. The April 2003 contract, which started on February 6, 2003.

The last two contracts were still open during the Gulf war. For these contracts, Tradesports provided us with daily price data through April 11, 2003, on which day the June and April contract prices were 98 and 97, respectively. We denote the price series of these contracts by MARCH, JUNE and APRIL (contract prices are divided by 100), and 
the respective daily price changes are denoted by DMARCH, DJUNE and DAPRIL. We use mostly the April and June contracts, which were still open during the war.

\section{INSERT FIGURE 1}

\section{INSERT TABLE 1}

The daily prices of the three contracts are presented in the two panels of Figure 1., and the statistics on the daily changes in the contract prices are presented in Table 1 . The data are divided by the date of initiation of the April contract, 2/6/2003; in each period we study two contracts trading with different maturity dates. Figure 1A depicts the prices of the March and June contracts up to 2/5/2003, and Figure 1B depicts the prices of the April and June contracts from the beginning of the April contract. As expected, JUNE > $M A R C H$ and $J U N E>A P R I L$ for all days because the probability of Saddam's fall was higher the further away was the expiration day of the contract. The contract prices show considerable variations, indicating the wide variation in anticipations of Saddam's fall as events progressed. In accordance with expectations, the shorter contracts (March and April) were more sensitive to news about Saddam's fall and hence their volatility is greater, with the difference being most apparent during the war. Once the war started, the probability of Saddam's fall was quite high, but there was a great deal of uncertainty about whether this would occur by the end of April, hence the sharp fall in the April price when it was found that Saddam had not been hit by U.S. bombs. We obtain that $\operatorname{Corr}(D M A R C H, D J U N E)=0.66$ and $\operatorname{Corr}(D A P R I L, D J U N E)=0.59$ in the periods 9/24/2002-2/5/2002 and 2/6/2002-4/11/2003, respectively. These correlations are not very high, because the relationship between the respective probabilities is not linear, and there is also a considerable amount of noise in the contract prices. 
Table 1 also presents the results of autoregressive models where $D P R I C E_{t}$ $\left(=D M A R C H_{t}, D A P R I L_{t}\right.$ and $\left.D J U N E_{t}\right)$ is regressed on its four lagged values, with the respective coefficients being $\rho_{l}$ to $\rho_{4}$. We obtain that for the March and June contracts, $\rho_{l}$ is negative and insignificant whereas for the April contract, for which the data series is shorter, ${ }^{2} \rho_{l}$ is positive and statistically significant. The positive $\rho_{l}$ for the April contract is, however, due to the war period only; before the war broke out, $\rho_{l}$ is negative and statistically insignificant, as are the coefficients $\rho_{l}$ for the other two contracts. For all contracts, none of the coefficients of lags 2,3 and 4 is significantly different from zero.

\subsection{The effect on stock prices: The S\&P 500 index}

We test the effect of the expectations of Saddam's fall on stock prices, employing the S\&P 500 stock index. $R M_{t}$ denotes the daily return on this index. We estimate the following models:

$$
R M_{t}=\alpha+\beta \cdot D P R I C E_{t}+u_{t} .
$$

$D P R I C E_{t}$ is the first difference of the Saddam contract price $\left(D P R I C E_{t}=D M A R C H_{t}\right.$, $D A P R I L_{t}$ or $\left.D J U N E_{t}\right)$. Estimations are done over three periods, where in each we have two contracts trading.

Period 1: The pre-war period preceding the inception of the April contract, 9/24/20022/5/2003 (92 days). We use March and June contract prices.

Period 2: The immediate pre-war period when both the April and the June contracts traded, 2/6/2003-3/14/2003 (26 days).

\footnotetext{
${ }^{2}$ On the bias in autoregressive coefficients in finite series, see Kendall (1954). The bias is greater the shorter the time series.
} 
Period 3: The war period, 3/17/2003-4/11/2003, the last 20 days of the sample. (The war actually started on 3/20/2003.) We use the April and June contract prices.

\section{INSERT TABLE 2}

The estimation results, presented in Table 2 show that in Period 3 - the war period - stock prices reacted positively and quite strongly to changes in the probability of Saddam's fall. The coefficient $\beta$ is positive and highly significant for both the April and June contracts, with the $R^{2}$ exceeding $40 \%$. The magnitude of the coefficients DJUNE means that a $10 \%$ rise in the probability of Saddam's fall raised stock prices by about $3 \%$. The effect of the April contract is about half that strong. The positive economic effect of the rise in the Saddam contract price is consistent with our interpretation of its meaning: a speedy conclusion to the war and the realization of benefits from the ousting of Saddam Hussein, such as lower oil prices and lower uncertainty and risk.

For the two periods before $2 / 6 / 2003, \beta$ is negative but very small and statistically insignificant for all contracts. ${ }^{3}$ This may reflect the mixed meaning of the Saddam contract prices before the war started: a rise in the probability of Saddam's fall may be good news, but it indicates a greater likelihood of a costly war breaking out.

Model (1) presents a joint test that (a) there is an association between the news about Saddam fall and stock prices, and (b) news is promptly incorporated into the prices of both Saddam contracts and stocks. However, if any of these markets are inefficient, the relationship between the two price series, $R M_{t}$ and $D P R I C E_{t}$, could be noncontemporaneous. To test possible lagged effects of $D P R I C E_{t}$ on $R M_{t}$, we estimate the following model:

\footnotetext{
${ }^{3}$ The Saddam contract prices are noisy (due to infrequent trading and large bid-ask spread), which could bias the estimated $\beta$ coefficient downward due to the well-known errors-in-the-variables problem.
} 


$$
R M_{t}=\alpha+\beta_{1} \cdot D_{P R I C E_{t}}+\beta_{2} \cdot D_{P R I C E} E_{t-1}+\beta_{3} \cdot \operatorname{DPRICE}_{t-2}+u_{t},
$$

where $D P R I C E_{t}=D M A R C H_{t}, D A P R I L_{t}$ or $D J U N E_{t}$. If the information in DPRICE $E_{t}$ were only partially incorporated into stock prices on the day that it was available, then $\beta_{2}$ and $\beta_{2}$ should have the same sign as $\beta_{1}$. Also, $\beta_{2}$ could have the same sign as $\beta_{l}$ because of a slight mismatch between the timing of our observations on Saddam contract prices and on stock prices. The contract prices are as of 24:00 hours Ireland time, which is 19:00 New York time. This means that news about Saddam, which arrived between 16:00 (market closing) and 19:00 New York time, was reflected in the market prices on the following day. However, these three hours are between the hours 0:00 and 3:00 (Iraq time), when little news is generated; hence the three hours mismatch is not expected to generate any significant effect.

On the other hand, if there were an overreaction of stock prices to information about Saddam's fall, then the sign of $\beta_{2}$ and possibly $\beta_{2}$ should be opposite to that of $\beta_{1}$.

The estimation results of model (2) are presented in Table 2. Consider the effect of the March contract, which was more actively traded than the June contract. For the first period, 9/24/02-2/5/03, all three coefficients of DMARCH are negative and of about the same magnitude, although none is significant. The cumulative effect of the three coefficients is -0.16 , meaning that a $10 \%$ increase in the probability of Saddam's fall lowered stock prices by $1.6 \%$. Regressing $R M_{t}$ on the cumulative change in the March contract price, $\left(D_{M A R C H}+D M A R C H_{t-1}+D M A R C H_{t-2}\right) / 3$, yields a coefficient of -0.16 with marginal significance, $t=1.76$. The persistence of a negative lagged effect of $D M A R C H_{t}$ on $R M_{t}$ is surprising since it suggests that news about Saddam's fall, which was publicly known and incorporated in the prices of the Saddam contract, was only 
gradually incorporated into stock prices. These results seem inconsistent with the belief that stock prices promptly reflect all publicly available information.

For the war period, the lagged effects of $D P R I C E_{t}$ indicate some overreaction to information. For both the April and June contracts, the sign of $\beta_{2}$ is opposite to that of $\beta_{1}$ and $\left|\beta_{2}\right|<\beta_{1}$, implying that the effect of $D P R I C E_{t}$ on one day was partially reversed on the following day. However, the coefficient $\beta_{2}$ for the June contract is not significantly different from zero, indicating that the price reversal is insignificant. For the April contract, the negative coefficient $\beta_{2}$ is statistically significant and the positive cumulative effect on stock prices is marginally significant. The strong reversal in the April contract may have been caused by the sharp and unusually large decline in the contract price after the outbreak of war, after it was disclosed that Saddam survived a bomb attack, which was quickly reversed when information arrived about the success of the U.S. campaign (see Figure 1, Panel B). As discussed earlier, the price of the April contract reacted to news more extremely than the price of the June contract because of the April contract's shorter time to expiration. Stock prices reacted more moderately to news, as did the price of the June contract, because once the war started, it was highly likely that Saddam would be defeated. The impact on stock prices was only to the extent of the time it would take to accomplish that end and the cost associated with it. Hence, both stock prices, which reflect long-run expectations, and the June contract price, which has a longer time to expiration, reacted more moderately to events than did the price of the short-term April contract.

In summary, while during the pre-war period the information about Saddam's fall was incorporated gradually into stock prices, during the war it was quickly incorporated. 
One explanation for this difference is greater investor exposure to news and discussions during the war, which heightened their attention and made stock prices respond more promptly to news. Thus, it is not only the content of the news that matters; the extent of its influence on stock prices also depends on the intensity with which the news is broadcasted to the public.

\subsection{Effects on sector stock indices, oil prices and exchange rates}

The analysis so far employed the S\&P 500 index, which comprises the stocks of large firms. It could well be that the prospect of the war and Saddam's fall have different effects on smaller firms' stocks. We examine this by employing two exchange-traded funds (ETFs) of S\&P 400 mid-cap firms and S\&P 600 small-cap firms. Their respective symbols are $I J H$ and $I J R$. (These ETFs are managed by BGI.) We estimate the following model:

$$
R j_{t}=\alpha_{j}+\beta_{j} D J U N E_{t}+\gamma_{j} R M R E S_{t}+u_{j t},
$$

where $R j_{t}$ is the return on stock index $j$. We use the two size-based stock indices: $j=I J H$, IJR. RMRES $S_{t}$ is the residual from a regression of $R M_{t}$, the daily return on the $\mathrm{S} \& \mathrm{P} 500$ stock index on $D J U N E_{t}$ (and a constant). This variable controls for factors that affect stock returns but are unrelated to the war. The inclusion of $R M R E S_{t}$ does not affect the point estimate of $\beta_{j}$ but it makes the estimate more accurate by reducing its standard error (thus raising the $t$ statistics). Model (3) is estimated for the last two subperiods: 26 days before the war and 20 days of the war. The results are presented in Table 3.

\section{INSERT TABLE 3}


The results show contrasting effects of the Saddam contract prices on stock returns before the war and during the war, and a difference between the extent of the reaction of large and small stocks before the war. During the war period, $\beta>0$, that is, the prices of both indices - mid-cap and small-cap - rise with the price of the Saddam contract. This is similar to what we observe in Table 2 for the S\&P 500 stock index. ${ }^{4}$ However, in the pre-war period we obtain $\beta<0$. That is, a rise in the Saddam contract price is associated with a significant decline in the prices of small-cap and mid-cap stocks, after controlling for market-wide effects. The $\beta$ coefficient of small firms is slightly more negative than the coefficient for mid-cap firms or the S\&P 500 firms, indicating that before the war started, smaller firms were considered more vulnerable to the likelihood of an outbreak of war, which was thought to be economically costly. ${ }^{5}$

The estimation results of model (3) are replicated for both Periods 2 and 3 using $D A P R I L_{t}$ in lieu of $D J U N E_{t}$. The results are qualitatively similar, that is, the estimated $\beta_{j}$ is positive and significant for Period 3 (war period) and negative and significant for Period 2 (pre-war period).

Next, model (3) is used to estimate the effect of the market's expectations of Saddam's fall on nine stock ETFs that pertain to the following sector stock indices: energy, consumer staples, consumer discretionary, industrial, materials, healthcare and utilities (these ETFs are managed by State Street). The results are presented in Table 3. Here too we obtain that for the war period, the $\beta$ coefficients of all sector indices are

\footnotetext{
${ }^{4}$ The high level of statistical significance of $\beta$ of the size indices, relative to that in Table 2 for $R M$ (the return on the S\&P 500 index), is due to the presence of RMRES on the RHS of model (3). Without this variable, the $t$ statistics of $\beta$ are much lower. For the war period, the $t$ statistics of $\beta$ are 2.84 for RIJH and 2.49 for $R I J R$, lower than that of $R M$. For the pre-war period, the $\beta$ coefficients become statistically insignificant when RMRES is not included in the model.

${ }^{5}$ We also estimated the model employing the Newey-West (1987) method with MA=1, to account for residual autocorrelation. The results are unchanged.
} 
positive and mostly significant, and they are negative and mostly significant for the short pre-war period. When using $D A P R I L_{t}$ in lieu of $D J U N E_{t}$ in model (4), the coefficient $\beta$ is again positive and similarly significant for the war period. For the pre-war period, $\beta$ is negative but most of the coefficients are not statistically significant.

The energy stock index stands out as having a low $\beta$ coefficient during the war, which is statistically insignificant. This is because of its dependence on the price of oil and on the economy at large. Given that before the war Iraq's oil sales were constrained, Saddam's fall should lower oil prices due to the prospective increase in Iraq's oil supply. So oil companies are subject to two conflicting effects: a successful war will be good for the economy, which should raise their stock prices, but will also lower oil prices, which will hurt them if they have oil reserves. The question is, what is the effect of the probability of Saddam's fall on oil prices. We estimate the following model:

$$
\operatorname{ROIL}_{t}=\alpha+\beta_{1} D_{J U N E_{t}}+\beta_{2} D J U N E_{t-1}+u_{j t},
$$

$R O I L_{t}$ denotes the daily return (percent change) on the spot price of crude oil (West

Texas Intermediate. Source: Wall Street Journal and Department of Energy. Prices are as of 4:00 pm New York time). The estimation results are presented in Table 4.

\section{INSERT TABLE 4}

Consistent with our analysis, a rise in the probability of Saddam's fall during the war reduced oil prices. Cumulatively over two days, a $1 \%$ increase in the probability of Saddam's fall lowered oil prices by nearly $1 \%$. While neither of the two slope coefficients is statistically significant, when we replace the two variables on the RHS of model (4) by their cumulative average, $\left(D J U N E_{t}+D J U N E_{t-1}\right) / 2$, we obtain a coefficient 
of -0.98 with $\mathrm{t}=1.89$, marginally significant. ${ }^{6}$ Also, using $D A P R I L_{t}$ in lieu of $D J U N E_{t}$, we obtain a coefficient of -0.32 with $t=2.20$, statistically significant. These results are consistent with our explanation for the weak effect of the probability of Saddam's fall on energy stocks prices due to conflicting effects. The resulting decline in oil prices on the one hand, and the economic improvement reflected in the rise in the stock market on the other hand, makes the total effect on energy stocks insignificantly different from zero. During the pre-war period, a rise in the Saddam contract price may have implied potential disruptions in oil supply, which would raise oil prices. Then, the effect of the Saddam contract prices on oil prices is positive but it is not statistically significant.

We also estimated model (3) for Period 1, 9/24/2002 to 2/5/2003 (92 days). The results are mixed. The coefficients $\beta$ of the two size-based indices are insignificantly different from zero. For the nine sector indices, the results are mixed. The coefficients $\beta$ of $X L I$ and $X L B$ (industrial and materials, respectively) are positive and significant, while the coefficient of $X L B$ (technology) is negative and significant. The rest are not statistically significant. Therefore it is hard to make a firm conclusion on the effect of the probability of Saddam's fall on stock prices during the pre-war period, which we denote as Period 1. This is consistent with our suggestion that the information reflected in the Saddam contract prices during that period was mixed. It is also consistent with our findings on the precarious statistical significance of the estimated coefficients during that period. For the energy stock index $(X L E)$, the coefficient was positive with marginal statistical significance, $t=1.77$. This may reflect the positive effect of DJUNE on oil prices during this period; however, the latter relationship has low statistical significance.

\footnotetext{
${ }^{6}$ Estimating the model by the Newey-West (1987) method with MA=1 produces $t=2.88$.
} 
Finally, we examine the response of the Euro/dollar exchange rate to the probability of Saddam's fall. We estimate a model similar to (4) with the dependent variable being $R E U R D O L_{t}$, the percent change in the Euro/dollar exchange rate on day $t$ :

$$
R E U R D O L_{t}=\alpha+\beta_{1} D J U N E_{t}+\beta_{2} D J U N E_{t-1}+u_{j t},
$$

A fast victory might strengthen the U.S. economy relative to the Euro-zone economies that did not participate in the war (or it might mitigate the damage to the U.S. economy relative to the European economies), while a prolonged war may weaken it. We therefore expect that $\beta_{1}>0$ during the war. Before the war, we have suggested, a rise in the probability of Saddam's fall conveys mixed signals: a greater likelihood of a war breaking out, which is costly for the economy, but also an ousting of a threat to the U.S., which is good news. Hence, before the war we expect $\beta_{1}<0$ if the dominating effect is the greater likelihood of a costly war, or $\beta_{l}=0$ if the two effects offset each other.

The exchange rates data, obtained from the Federal Reserve Bank, are as of noon New York time, which is 7 hours before the close of trading on the Saddam contracts. However, these 7 hours are night time in Iraq, when not much news is generated. Indeed, in spite of this mismatch in the timing of the foreign exchange rates and the Saddam contract prices, there is no significant lagged effect of the change in the Saddam contract prices on exchange rates.

The estimation results of model (4') are presented in Table 4. During the war period, $\beta_{l}$ is positive and significant. That is, a rise in the probability of Saddam's fall, which also indicated a speedy conclusion of the war, strengthened the dollar against the Euro. The war-related events explain nearly $30 \%$ of the exchange rate variability, as indicated by $R^{2}$. Using the April contract price, we obtain an even higher explanatory 
power of the model: $R^{2}=0.55$. For the pre-war period, $\beta_{1}<0$ meaning that the rise in the probability of Saddam's fall, which also indicated that a war was likely to break out, weakened the U.S. dollar against the Euro. However, this effect is not statistically significant from zero.

\section{Comparison with Leigh, Wolfers and Zitzewitz (2003)}

In a recent independent study, Leigh, Wolfers and Zitzewitz (2003) analyze the effects of Saddam contracts prices on financial markets, using data on three contracts (December 2002, March 2003 and June 2003) up to February 6, 2003, which correspond to Period 1 in our analysis. For this period, Period 1 in our analysis, their results are similar to ours: there is a negative relationship between the probability of Saddam's fall and stock prices. Leigh et al. (2003), like we do, interpret the probability of Saddam's fall during that period as the probability of war breaking out prior to the contract expiration date. Thus, the higher the Saddam contract price, the greater the expected economic costs and the risks due to the war. We add that a rise in the Saddam contract prices also meant a possible benefit from the ousting of Saddam Hussein, which works in the opposite direction and therefore weakens the negative effects of the prospects of war. Hence the weak negative relationship between Saddam's contract prices and stock prices before the war.

However, for the war period, which is beyond Leigh et al.'s (2003) sample period, we obtain a positive relationship between Saddam contract prices and stock prices. This is because once the war became certain, there was a change in the interpretation of Saddam contract prices, as discussed in the introduction. Higher contract prices meant 
faster conclusion of the war and lower expected cost and risk, which also works in the same direction as the benefit from the ousting of Saddam Hussein. We also obtain that during the war, the effect on oil prices of the probability of Saddam's fall was negative because a speedy end to the war also meant a potential increase in Iraq's oil supply. Before the war, when a rise in the probability of Saddam's fall was interpreted as a greater likelihood of war and potential disruption of oil supply, Leigh et al. (2003) obtain that the effect on oil prices was positive.

\section{Concluding remarks}

This paper studies the extent to which political events move stock prices by examining the effects of changes in the market's expectations of Saddam Hussein's fall from power. The expectations are obtained from the prices of traded contracts that promised a fixed amount if Saddam were out of power by the contracts' expiration dates. We obtain that during the war, a rise in these expectations had significant positive effects on stock prices. The explanatory power of the model is over $40 \%$. In addition, a rise in the probability of Saddam's fall strengthened the U.S. dollar against the Euro and lowered oil prices. But these results apply only to the war period. Before the war, a rise in the probability of Saddam's fall lowered stock price (the effect is not always statistically significant). It also had a positive effect on oil prices and it weakened the U.S. dollar against the Euro (the effects are not statistically significant).

The differences in the effects of the probability of Saddam's fall between the two periods - the war period and the pre-war period - indicate a change in the interpretation of the news reflected in the Saddam contract prices. Before the war, a rise in the Saddam 
contract price meant, in addition to a rise in the probability of Saddam being ousted, a rise in the probability of a war breaking out, which could be costly to the U.S. economy. But conditional on the war breaking out, a rise in the probability of Saddam's fall by a certain (nearby) date meant a speedy end to the war, lower cost on the U.S. economy and the realization of the benefits it produces, such as lower oil prices and lower risk of terror attacks.

The very weak explanatory value of news about Saddam's fall before the war also suggests that moves in stock prices reflect something other than fundamental values, as suggested by Cutler et al. (1989). And, it could be that fads and media attention affect the weight that the public attributes to news and the extent to which the news is incorporated into stock prices. We detect a gradual adjustment of stock prices to information before the war; during the war, with media attention focused on it - that is, expectations about Saddam's fall are big news -the effect on stock prices, oil prices and exchange rates is quite strong, and we observe a prompt adjustment of stock prices to information. 


\section{$\underline{\text { References }}$}

Bailey, Warren and Peter Chung, 1995, "Exchange Rate Fluctuations, Political Risk, and Stock Returns: Some Evidence from an Emerging Market." Journal of Financial and Quantitative Analysis 30, 541-61.

Cutler, David M., James M. Poterba and Lawrence H. Summers, 1989, "What Moves the Stock Market?” Journal of Portfolio Management 15 (Summer), pp. 4-11.

Erb, Claude B., Campbell R. Harvey and Tadas E. Viskanta, 1995, "Inflation and World Equity Selection.” Financial Analysts Journal, November-December, 28-42.

Frey, Bruno S. and Marcel Kucher, 2000, "History as Reflected in Capital Markets: The Case of World War II." Journal of Economic History 60, 468-496.

Kendall, M.G., 1954, "Note on Bias in the Estimation of Autocorrelation." Biometrika 41, 403-404.

Leigh, Andrew, Justin Wolfers and Eric Zitzewitz, 2003, "What Do Financial Markets Think of War with Iraq?” NBER Working Paper \# 9587, March.

Newey, Whitney K. and Kenneth D. West, 1987, "A Simple, Positive Semi-Definite Heteroskedasticity and Autocorrelation Consistent Covariance Matrix." Econometrica 55, pp. 703-708.

Nordhaus, William D., 2002, "The Economic Consequences of a War with Iraq." Working Paper, Yale University Department of Economics and the NBEW, December.

Waldenstrom, Daniel and Bruno S. Frey, 2002, "How Government Bond Prices Reflect Wartime Events: The Case of the Stockholm Market." University of Zurich Working Paper \#102.

White, Halbert, 1980, “A Heteroskedasticity-Consistent Covariance Matrix Estimator and a Direct Test for Heteroskedasticity.” Econometrica 48, pp. 817-838. 
Table 1: Statistics on daily changes in the Saddam contract prices

The Saddam contract promises $\$ 1.00$ if Saddam is out of power by the contract's expiration day, which is the last day of the respective month. The daily change in the contract price, DPRICE, is denoted DMARCH, DAPRIL and DJUNE according to the contract's expiration day. $R M$ is the daily return on the S\&P 500 index. $\rho_{k}$ are the coefficients obtained from regressing $D P R I C E_{t}$ on its four lags and a constant. The $t$ statistics, in parentheses, employ White's (1980) standard errors.

\begin{tabular}{|l|l|l|l|l|l|l|l|l|l|l|}
\hline Contract & Period & $\mathrm{N}$ & Mean & $\mathrm{SD}$ & Min & Max & $\rho_{1}$ & $\rho_{2}$ & $\rho_{3}$ & $\rho_{4}$ \\
\hline DMARCH & $\begin{array}{l}9 / 24 / 02- \\
2 / 5 / 03\end{array}$ & 91 & -0.003 & 0.034 & -0.11 & 0.12 & -0.161 & -0.135 & -0.035 & 0.065 \\
& & & & & & $(1.23)$ & $(1.05)$ & $(0.22)$ & $(0.93)$ \\
\hline DAPRIL & $\begin{array}{l}2 / 6 / 03- \\
4 / 11 / 03\end{array}$ & 45 & 0.0084 & 0.055 & -0.12 & 0.15 & 0.265 & 0.028 & 0.057 & -0.11 \\
& & & & & & $(2.28)$ & $(0.14)$ & $(0.31)$ & $(0.06)$ \\
\hline DJUNE & $9 / 24 / 02-$ & 137 & 0.0036 & 0.034 & -0.07 & 0.12 & -0.161 & 0.013 & 0.054 & 0.065 \\
& $4 / 11 / 03$ & & & & & & $(1.53)$ & $(0.15)$ & $(0.58)$ & $(0.82)$ \\
\hline$R M$ & $9 / 24 / 02-$ & 137 & 0.006 & 0.016 & -0.035 & -0.047 & -0.150 & 0.117 & 0.015 & -0.003 \\
& $4 / 11 / 03$ & & & & & & $(1.61)$ & $(1.04)$ & $(0.15)$ & $(0.04)$ \\
\hline
\end{tabular}


Table 2: The lagged effect of the probability of Saddam's fall on stock returns

Estimation of the models:

$$
\begin{aligned}
& R M_{t}=\alpha+\beta D P R I C E_{t}+u_{t}, \\
& R M_{t}=\alpha+\sum_{j=0}^{2} \beta_{j} D P R I C E_{t-j}+u_{t} .
\end{aligned}
$$

$R M_{t}$ is the daily return on the S\&P 500 stock index. DPRICE $E_{t}$ is the daily change in the price of a contract that promises $\$ 1.00$ if Saddam is out of power by the contract's expiration day, which is the last day of the respective month. $\rho$ is the residual

\begin{tabular}{|c|c|c|c|c|c|c|c|}
\hline Period & Contract & Constant & $D_{P R I C E_{t}}$ & ${ }_{D P R I C E_{t-1}}$ & $D_{P R I C E_{t-2}}$ & $R^{2}$ & $\rho$ \\
\hline \multirow{4}{*}{$\begin{array}{l}9 / 24 / 02- \\
2 / 5 / 03, \\
91 \text { days }\end{array}$} & \multirow[t]{2}{*}{ March } & $\begin{array}{l}0.0329 \\
(0.18)\end{array}$ & $\begin{array}{l}-0.041 \\
(1.09)\end{array}$ & & & 0.01 & $\begin{array}{l}-0.160 \\
(1.40)\end{array}$ \\
\hline & & $\begin{array}{l}-0.000 \\
(0.27)\end{array}$ & $\begin{array}{l}-0.051 \\
(1.26)\end{array}$ & $\begin{array}{l}-0.065 \\
(1.25)\end{array}$ & $\begin{array}{l}-0.043 \\
(1.11)\end{array}$ & 0.03 & $\begin{array}{l}-0.174 \\
(1.57) \\
\end{array}$ \\
\hline & \multirow[t]{2}{*}{ June } & $\begin{array}{l}0.0005 \\
(0.26)\end{array}$ & $\begin{array}{l}-0.001 \\
(0.03)\end{array}$ & & & 0.00 & $\begin{array}{c}-0.147 \\
(1.28)\end{array}$ \\
\hline & & $\begin{array}{l}0.000 \\
(0.04)\end{array}$ & $\begin{array}{l}0.001 \\
(0.01)\end{array}$ & $\begin{array}{l}-0.046 \\
(0.74)\end{array}$ & $\begin{array}{l}-0.025 \\
(0.54)\end{array}$ & 0.00 & $\begin{array}{l}-0.154 \\
(1.34)\end{array}$ \\
\hline \multirow{4}{*}{$\begin{array}{l}2 / 6 / 03- \\
3 / 14 / 03, \\
26 \text { days }\end{array}$} & \multirow[t]{2}{*}{ April } & $\begin{array}{l}0.000 \\
(0.01)\end{array}$ & $\begin{array}{l}-0.035 \\
(0.45)\end{array}$ & & & 0.01 & $\begin{array}{l}-0.134 \\
(0.74)\end{array}$ \\
\hline & & $\begin{array}{l}0.000 \\
(0.02)\end{array}$ & $\begin{array}{l}-0.008 \\
(0.07)\end{array}$ & $\begin{array}{l}-0.035 \\
(0.28)\end{array}$ & $\begin{array}{l}0.013 \\
(0.19)\end{array}$ & 0.01 & $\begin{array}{c}-0.061 \\
(0.34)\end{array}$ \\
\hline & \multirow[t]{2}{*}{ June } & $\begin{array}{l}-0.000 \\
(0.54)\end{array}$ & $\begin{array}{l}-0.056 \\
(1.02)\end{array}$ & & & 0.03 & $\begin{array}{l}-0.120 \\
(0.68) \\
\end{array}$ \\
\hline & & $\begin{array}{l}-0.000 \\
(0.54)\end{array}$ & $\begin{array}{l}-0.058 \\
(0.91)\end{array}$ & $\begin{array}{l}-0.005 \\
(0.09)\end{array}$ & $\begin{array}{l}-0.041 \\
(0.60)\end{array}$ & 0.04 & $\begin{array}{c}-0.118 \\
(0.68)\end{array}$ \\
\hline \multirow{4}{*}{$\begin{array}{l}3 / 17 / 03- \\
4 / 11 / 03, \\
20 \text { days }\end{array}$} & \multirow[t]{2}{*}{ April } & $\begin{array}{l}0.000 \\
(0.13)\end{array}$ & \begin{tabular}{|l|}
0.139 \\
$(3.30)$
\end{tabular} & & & 0.41 & $\begin{array}{l}-0.113 \\
(0.40)\end{array}$ \\
\hline & & $\begin{array}{l}0.001 \\
(0.61)\end{array}$ & \begin{tabular}{|l|}
0.177 \\
$(4.60)$
\end{tabular} & $\begin{array}{l}-0.113 \\
(2.66)\end{array}$ & $\begin{array}{l}0.009 \\
(0.25)\end{array}$ & 0.65 & $\begin{array}{l}-0.076 \\
(0.29)\end{array}$ \\
\hline & \multirow[t]{2}{*}{ June } & $\begin{array}{l}-0.001 \\
(0.15)\end{array}$ & \begin{tabular}{|l|}
0.294 \\
$(3.82)$ \\
\end{tabular} & & & 0.43 & $\begin{array}{l}-0.292 \\
(1.28)\end{array}$ \\
\hline & & $\begin{array}{l}-0.000 \\
(0.02)\end{array}$ & \begin{tabular}{|l|}
0.281 \\
$(3.59)$
\end{tabular} & $\begin{array}{l}-0.066 \\
(0.88)\end{array}$ & $\begin{array}{l}0.035 \\
(0.55)\end{array}$ & 0.46 & $\begin{array}{l}-0.272 \\
(1.19)\end{array}$ \\
\hline
\end{tabular}
autocorrelation. The $t$ statistics, in parentheses, employ White's (1980) standard errors. 
Table 3: The effects of the probability of Saddam's fall on returns on stock indices

The effects on stock prices

$$
R j_{t}=\alpha_{j}+\beta_{j} D J U N E_{t}+\gamma_{j} R M R E S_{t}+u_{j t},
$$

$R j_{t}$ is the daily return on stock index $j$. DJUNE $E_{t}$ is the daily change in the value of the futures contract that promises $\$ 1.00$ if Saddam is out of power by the end of June.

$R M R E S_{t}$ is the residual from a regression of $R M_{t}$, the daily return on the $\mathrm{S} \& \mathrm{P} 500$ index on $D J U N E_{t}$ (and a constant).

The $t$-statistics, in parentheses, employ White's (1980) standard errors. Period 2, the prewar period, is $2 / 6 / 2003-3 / 14 / 2003$ (26 days). Period 3, the war period, is $3 / 17 / 2003$ -

4/11/2003 (20 days).

The table presents the coefficients $\beta_{i}$ from this model.

\begin{tabular}{|l|l|l|l|}
\hline Group & Dependent variable & $\begin{array}{l}\text { Period 2 } \\
\text { (pre-war) }\end{array}$ & $\begin{array}{l}\text { Period 3 } \\
\text { (war) }\end{array}$ \\
\hline Size indices & RIJH & -0.049 & 0.193 \\
& S\&P 400 mid-cap & $(2.01)$ & $(7.05)$ \\
\cline { 2 - 4 } & RIJR & -0.069 & 0.186 \\
& S\&P 600 small-cap & $(4.82)$ & $(9.78)$ \\
\hline Sector indices & RXLE & -0.039 & 0.059 \\
& Energy & $(1.33)$ & $(1.18)$ \\
\cline { 2 - 4 } & RXLP & -0.069 & 0.237 \\
& Consumer staples & $(3.58)$ & $(7.65)$ \\
\cline { 2 - 4 } & RXLY & -0.037 & 0.380 \\
& Consumer discretionary & $(1.64)$ & $(21.49)$ \\
\cline { 2 - 4 } & RXLI & -0.100 & 0.260 \\
& Industrials & $(3.06)$ & $(8.14)$ \\
\cline { 2 - 4 } & RXLB & -0.083 & 0.332 \\
& Materials & $(3.47)$ & $(6.82)$ \\
\cline { 2 - 4 } & RXLK & -0.074 & 0.390 \\
& Technology & $(2.74)$ & $(11.18)$ \\
\cline { 2 - 4 } & RXLF & -0.087 & 0.297 \\
& Financials & $(5.77)$ & $(5.47)$ \\
\cline { 2 - 4 } & RXLV & -0.011 & 0.218 \\
& Healthcare & $(0.63)$ & $(13.47)$ \\
\cline { 2 - 4 } & RXLU & -0.056 & 0.156 \\
& Utilities & $(1.63)$ & $(4.30)$ \\
\hline
\end{tabular}


Table 4: The effects on oil prices and exchange rates

$$
R j_{t}=\alpha_{j}+\beta_{j 0} D J U N E_{t}+\beta_{j 1} D J U N E_{t-1}+u_{j t},
$$

$R j_{t}$ is either $R O I L_{t}$, the daily return on the spot price of oil, West Texas Intermediate, or $R E U R D O L_{t}$, the daily return on the Euro/Dollar spot exchange rate. DJUNE $E_{t}$ is the daily change in the price of a contract that promises $\$ 1.00$ if Saddam is out of power by the last day of June, the contract's expiration day. $\rho$ is the residual autocorrelation. The $t$ statistics, in parentheses, employ White's (1980) standard errors. The pre-war period is $2 / 6 / 2003-3 / 14 / 2003$ (26 days). The war period is 3/17/2003-4/11/2003 (20 days).

\begin{tabular}{|c|c|c|c|c|c|c|}
\hline Period & Period & Constant & $D_{J U N E_{t}}$ & $D_{J U N E_{t-1}}$ & $R^{2}$ & $\rho$ \\
\hline \multirow{4}{*}{$\begin{array}{l}\text { Oil, } \\
\text { West } \\
\text { Texas } \\
\text { Intermediate }\end{array}$} & \multirow[t]{2}{*}{ Pre-war } & $\begin{array}{l}0.001 \\
(0.32)\end{array}$ & $\begin{array}{l}0.095 \\
(1.25)\end{array}$ & & 0.03 & $\begin{array}{l}0.41 \\
(1.73) \\
\end{array}$ \\
\hline & & $\begin{array}{l}0.002 \\
(0.35)\end{array}$ & $\begin{array}{l}0.090 \\
(1.06)\end{array}$ & $\begin{array}{l}-0.037 \\
(0.25)\end{array}$ & 0.03 & \begin{tabular}{|l|}
0.41 \\
$(1.74)$ \\
\end{tabular} \\
\hline & \multirow[t]{2}{*}{ War } & $\begin{array}{l}-0.005 \\
(0.29)\end{array}$ & $\begin{array}{l}-0.410 \\
(1.03)\end{array}$ & & 0.04 & $\begin{array}{l}0.33 \\
(0.92)\end{array}$ \\
\hline & & $\begin{array}{l}-0.001 \\
(0.06)\end{array}$ & $\begin{array}{l}-0.499 \\
(1.55)\end{array}$ & $\begin{array}{l}-0.482 \\
(1.48)\end{array}$ & 0.10 & $\begin{array}{l}0.34 \\
(0.87) \\
\end{array}$ \\
\hline \multirow{4}{*}{$\begin{array}{l}\text { Exchange } \\
\text { rate, } \\
\text { Euro/dollar }\end{array}$} & \multirow[t]{2}{*}{ Pre-war } & $\begin{array}{l}-0.001 \\
(0.54)\end{array}$ & $\begin{array}{l}-0.044 \\
(1.30)\end{array}$ & & 0.10 & $\begin{array}{l}0.29 \\
(1.13) \\
\end{array}$ \\
\hline & & $\begin{array}{l}-0.000 \\
(0.41)\end{array}$ & $\begin{array}{l}-0.041 \\
(1.15)\end{array}$ & $\begin{array}{l}0.022 \\
(1.16)\end{array}$ & 0.12 & $\begin{array}{l}0.30 \\
(1.09) \\
\end{array}$ \\
\hline & \multirow[t]{2}{*}{ War } & $\begin{array}{l}-0.001 \\
(0.78)\end{array}$ & $\begin{array}{l}0.102 \\
(3.78)\end{array}$ & & 0.28 & $\begin{array}{l}-0.20 \\
(0.95) \\
\end{array}$ \\
\hline & & $\begin{array}{l}-0.001 \\
(0.87)\end{array}$ & $\begin{array}{l}0.105 \\
(3.33)\end{array}$ & $\begin{array}{l}0.017 \\
(0.46)\end{array}$ & 0.29 & \begin{tabular}{|l|}
-0.21 \\
$(1.08)$
\end{tabular} \\
\hline
\end{tabular}


Figure 1

Daily closing prices of the March 2003, April 2003 and June 2003 contracts on Saddam's fall, as traded on Sportstrades.com. The prices are as of 24:00 of the day, Ireland time. The contract promises to pay 100 if by the last day of the contract's month Saddam is "not recognized internationally as the leader of Iraq." Panel A includes the March and June contracts, and Panel B includes the April and June contracts.

A: $9 / 24 / 2002-2 / 5 / 2003$

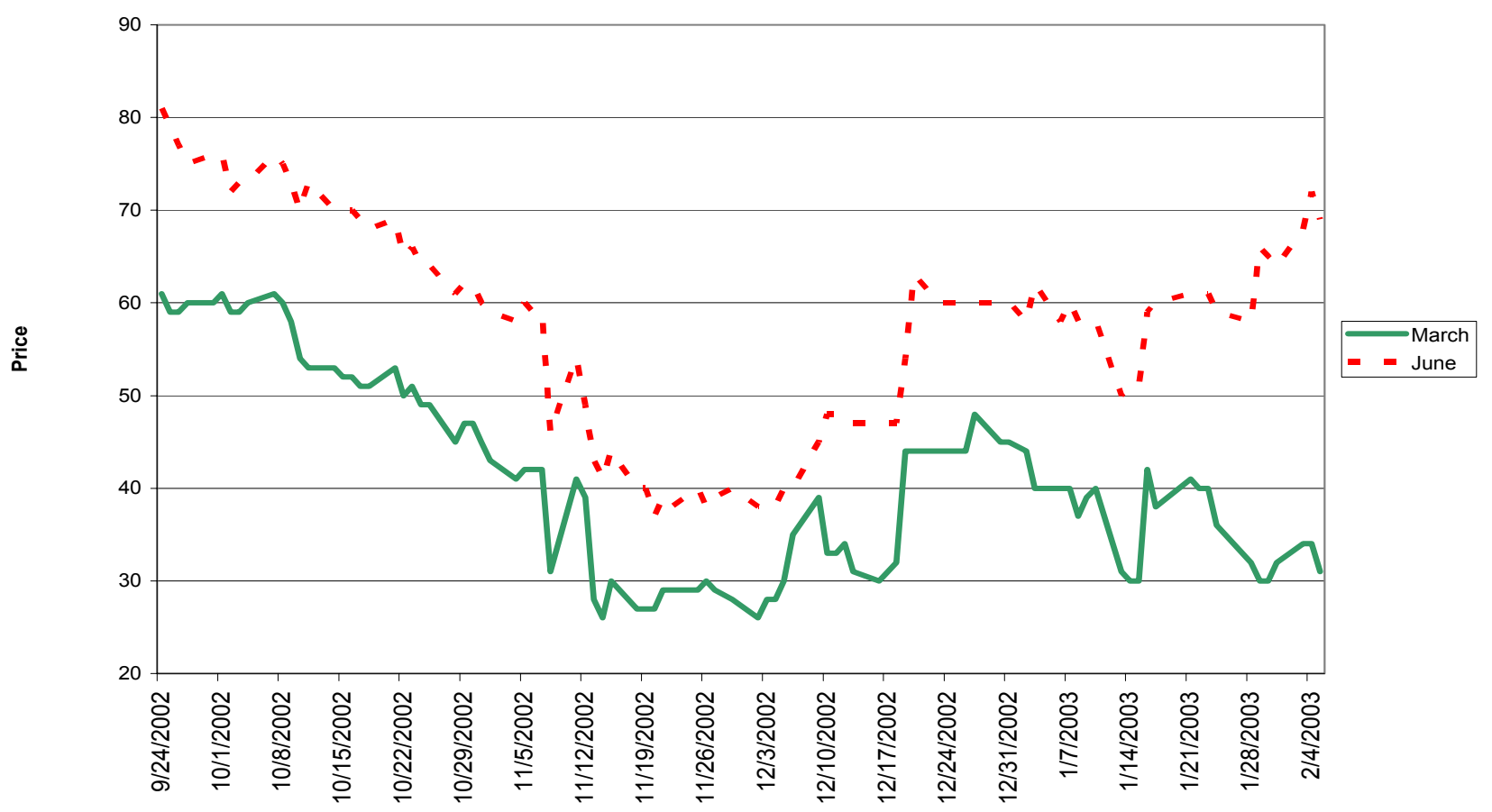


B: $2 / 6 / 2003-4 / 11 / 2003$

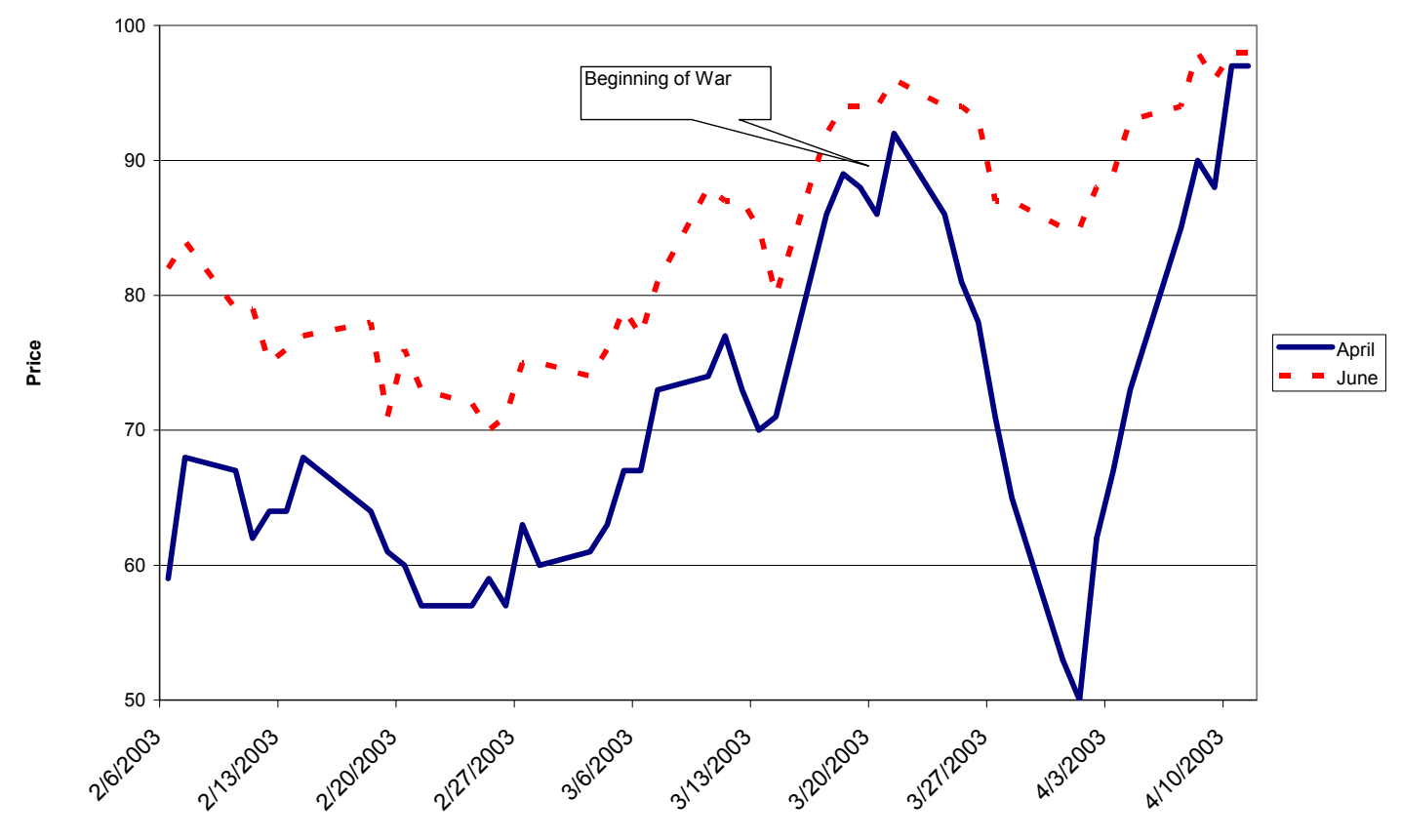

